it is to be used, and that, as far as possible, it should be independent of references. The recent collection of articles on Forest Conservation, published by the Dominion Forest Service, will be valuable supplementary reading.

It is expected that the unit on forestry will be compulsory, and one great advantage of having such material placed in texts on General Science instead of printed separately is that it will be in the hands of every teacher and pupil. Experience will no doubt indicate the need for improvements but in the meantime a step has been taken towards a more general and intelligent interest in the management of forest land. Without it, progress in forestry will be slow and confused by ill-considered schemes based on slogans and sentiment rather than knowledge and commonsense. We expect that eventually material will also be included in texts on social studies. Nova Scotia members are endeavouring to interest their province in the teaching of forestry. Perhaps other sections of the Society may see an opportunity to do similar work.

\title{
FOREST PROTECTION CONFERENCE IN NEW BRUNSWICK
}

A conference on Forest Protection was called at Fredericton by the Honorable Mr. F. W. Pirie, LL.D., Minister of Lands and Mines of New Brunswick, on March 18 and marked a further step in the forestry progress of the province. It was attended by over 200 delegates, including representatives of the Canadian Forestry Association and the Maritime Section of the Canadian Society of Forest Engineers. The purpose was to arouse further interest in forest protection, and particularly to make additional preparations to meet the hazards of the coming fire season. Of special importance was the attendance of a five-man fire prevention committee from each of the sixteen county councils.

Among those addressing the conference were I. C. Marritt, Senior Ex. tension Forester for Ontario, who spoke on the management of farm wood. lots, and G. W. I. Creighton, Chief Forester of Nova Scotia, who spoke on Forest Fire Protection in his province. The dinner address was given by Dr. N. A. M. MacKenzie, K.C., President of the University of New Brunswick, who spoke very effectively on the possibilities of fire through enemy action and referred to the need for leadership in management of our forests, and the influence of the College of Forestry. The LieutenantGovernor, the Premier, and the Leader of the Opposition were among the other speakers. The subject of woodlot management aroused considerable interest and reference was made to the need for an extension forester.

An observer can see in the great interest taken in such a conference the accumulated results of thirty-five years of forestry training at the University of New Brunswick. Graduates in forestry were first employed by the Province of New Brunswick in the year 1916 and have since taken an active part in forming New Brunswick's forest policy. In 1917, the first Chief Forester, G. H. Prince, was appointed and requested to draft the New Brunswick Forest Fires Act and to organize New Brunswick's Forest Service. The Act was passed in 1918 and the present Forest Service 
organized in the same year. In spite of considerable opposition, the first fire lookout tower was placed in operation in 1918. This system has proved its value many times over and the number of towers has grown to thirty-five. Again, in 1924, New Brunswick became the first province to appoint a graduate forester as deputy minister in charge of forests. The policy was followed by Quebec fourteen years later, and by Ontario, but not until 1941. Foresters employed with the Government of New Bruns. wick and with the forest industries of the province now number over thirty and even the most casual observer can see the improvement in the forest policy of the province that has been brought about directly and indirectly by the establishment of the University of New Brunswick Forest School and its activities during the past thirty-five years.

\section{NEW ENGLAND SECTION, SOCIETY OF AMERICAN FORESTERS}

The annual meeting of the New England Section, Society of American Foresters was held at Springfield, Massachusetts on February 26 and 27 with C. S. Herr as chairman. Officers elected for the ensuing year were F. M. Callward, Chairman, J. D. Curtis, Vice-Chairman, and A. D. Rhodes, Secretary-Treasurer. L. A. Nix was elected Eastern Canadian representative on the executive council.

The agenda of the meeting was largely in the form of reports by the various committees of the section. Some of these reports called forth lively discussion. Certain revisions of the forest practice rules which were recently published in the Forestry Chronicle were suggested. The advisability of extended discussion before final adoption of these rules was generally ad. mitted. A discussion on the need for greater vigilance and increased preparations to combat fires of incendiary origin closely paralleled discussions at recent meetings of the Maritime Section, Canadian Society of Forest Engineers and of the new Brunswick Section, Canadian Forestry Association.

A considerable argument developed over the Omnibus Bill which proposes public regulation of private cutting and over the report of the Committee on Policy. The latter report is to be published in the Journal of Forestry.

The report of the Committee on Forest Insects and Diseases again illustrated the common problems of New England and adjacent regions of Canada. The forest insect situation in the Maritimes was presented by $A$. S. West, Jr., of the University of New Brunswick.

The makers of the Indian Fire Pump donated three pumps as door prizes at the annual banquet. This practice was an innovation to those foresters who have basked in the hospitality of the "pump room" while attending meetings of the Canadian Society of Forest Engineers.

\section{FRASER COMPANIES LIMITED, PROMOTE EDUCATION IN WOODLOT MANAGEMENT}

E. L. Howie, in a recent letter, outlined work which has been done in Madawaska County, N.B., to encourage better management of farm 